This page intentionally left blank 
VÍCTOR FERRERES COMELLA

\section{Constitutional Courts}

\section{${ }^{\text {AND Democratic Values }}$}

A EUROPEAN PERSPECTIVE 
Copyright (C) 2009 by Yale University.

All rights reserved.

This book may not be reproduced, in whole or in part, including illustrations, in any form (beyond that copying permitted by Sections 107 and 108 of the U.S. Copyright Law and except by reviewers for the public press), without written permission from the publishers.

Set in FontShop Scala and Scala Sans by Duke \& Company, Devon, Pennsylvania. Printed in the United States of America.

Library of Congress Control Number: 2009904635

ISBN 978-0-300-14867-1 (paperback : alk. paper)

A catalogue record for this book is available from the British Library.

This paper meets the requirements of ANSI/NISO Z39.48-1992 (Permanence of Paper).

$\begin{array}{llllllllll}10 & 9 & 8 & 7 & 6 & 5 & 4 & 3 & 2 & 1\end{array}$ 
To Owen Fiss 
This page intentionally left blank 